\title{
PENCEMARAN TELUR NEMATODA USUS PADA LALAPAN DAUN POHPOHAN, DAUN KENIKIR DAN BUAH KACANG PANJANG YANG DIJUAL DI PASAR TRADISIONAL EMBRIO KECAMATAN MAKASAR, JAKARTA TIMUR DAN HUBUNGANNYA DENGAN TINDAKAN PENCUCIAN
}

\author{
*Sumiati Bedah ${ }^{1)}$, Diniar Dwi Astuti ${ }^{11}$ \\ ${ }^{1}$ Program Studi Analis Kesehatan, Fakultas Kesehatan, Universitas Mohammad Husni Thamrin \\ Correspondence author: Sumiati Bedah, Sumiatibedah@yahoo.co.id, Jakarta, Indonesia
}

\begin{abstract}
ABSTRAK
Kecacingan merupakan masalah kesehatan masyarakat di banyak negara termasuk di Indonesia. Angka kecacingan di Indonesia tahun 2012-2013 mencapai 28\%. Spesies yang paling banyak menginfeksi adalah Ascaris lumbricoides, Trichuris trichiura dan cacing tambang. Salah satu sumber infeksi yang sering terjadi adalah pencemaran lalapan, dimana lalapan ini biasa dimakan mentah. Angka pencemaran lalapan yang pernah dilaporkan adalah 26,19\% pada lalapan selada, kubis dan kemangi. Penelitian ini bertujuan untuk menentukan angka pencemaran telur nematoda usus pada lalapan daun pohpohan, kenikir dan kacang panjang yang dijual di Pasar Tradisional Embrio dan hubungannya dengan tindakan pencucian. Penelitian ini merupakan penelitian deskriptif dengan desain survei potong lintang. Sampel adalah lalapan daun pohpohan, kenikir dan kacang panjang yang masing-masing jenis berjumlah 50 sehingga seluruhnya berjumlah 150. Pemeriksaan spesimen dilakukan dengan menggunakan teknik konsentrasi metode sedimentasi. Hasil menunjukan bahwa besarnya angka pencemaran adalah 4,7\% (7/150). Jenis telur cacing yang ditemukan adalah Ascaris lumbricoides dan Trichuris trichiura. Tindakan pencucian yang berhubungan dengan pencemaran telur nematoda usus adalah cara penggantian air pencuci dan cara pencucian dengan pencampuran lebih dari satu jenis lalapan, sedangkan dengan frekuensi pencucian tidak berhubungan. Disarankan bagi penjual dan penggemar lalapan mentah agar mencuci lalapan dilakukan dengan air mengalir dan tidak mencampur lebih dari satu jenis lalapan serta lebih memperhatikan tempat untuk menyimpan dan menjual lalapan.
\end{abstract}

Kata kunci $\quad$ : Lalapan, nematoda usus, pencemaran, tindakan pencucian.

\begin{abstract}
Worms is a public health problem in many countries, including Indonesia. The number of worms in Indonesia in 2012-2013 reached 28\%. The species that infect the most are Ascaris lumbricoides, Trichuris trichiura and hookworms. One source of infection that occurs is contamination of fresh vegetables, where fresh vegetables are usually eaten raw. The reported number of fresh vegetables is $26.19 \%$ in lettuce, cabbage and basil. This study aims to determine the number of intestinal nematode egg contamination on fresh vegetables of pohpohan leaves, kenikir and long beans sold in the Embryo Traditional Market and the washing action. This research is a descriptive study with a cross sectional survey design. Samples were fresh vegetables of pohpohan leaves, kenikir and long beans, each of which was equipped with 150. Examination of specimens was carried out using the concentration technique of the sedimentation method. The results show that the pollution rate is $4.7 \%$ (7/150). The types of worm eggs found were Ascaris lumbricoides and Trichuris trichiura. Washing action related to intestinal nematode egg contamination is a way of changing air washer and washing method by mixing more than one type of fresh vegetables, while washing frequency is not related. It is advisable for sellers and fans of raw fresh vegetables to be able to do it with air flow and not mix more than one type of fresh vegetables and pay more attention to the place to store and sell fresh vegetables.
\end{abstract}

Key words: Fresh Vegetables, intestinal nematodes, contamination, washing action. 


\section{PENDAHULUAN}

Lebih dari 1,5 milyar orang penduduk dunia terinfeksi Soil Transmitted Helminth. Kasus tertinggi terjadi di negara-negara Afrika Sub-Sahara, Amerika, Cina dan Asia Timur. Di Indonesia angka kesakitan karena terinfeksi cacing usus cukup tinggi, pada tahun 2012-2013 mencapi 28\% (Sulistyaningsih,2019). Jumlah infeksi kecacingan di Asia Tenggara, termasuk Indonesia, dipengaruhi oleh kondisi sanitasi lingkungan dan hygiene perorangan yang buruk serta pendidikan yang rendah dan juga dikarenakan letak geografis Indonesia di daerah tropis yang mempunyai iklim yang panas akan tetapi lembab. Pada lingkungan yang memungkinkan, cacing usus dapat berkembang biak dengan baik terutama oleh cacing yang ditularkan melalui tanah (Soil Transmitted Helminth). Di Indonesia, nematoda usus yang masih menjadi masalah kesehatan masyarakat adalah Ascaris lumbricoides, cacing tambang dan Trichuris trichiura. Salah satu sumber penularannya adalah air dan lumpur yang digunakan dalam budidaya sayuran. Tanah, sayur-sayuran, dan air merupakan media transmisi yang penting (Nugroho, 2010).

WHO menyatakan bahwa lebih dari separuh masalah kesehatan negara berkembang adalah penyakit kecacingan. Hal ini dipengaruhi oleh perilaku hidup masyarakat yang masih belum bisa menjaga kesehatan lingkungan dan sanitasi yang buruk. Dampak yang disebabkan oleh infeksi cacing adalah menurunnya kondisi kesehatan, gizi, kecerdasan dan produktifitas, sehingga secara ekonomi banyak menyebabkan kerugian dan dapat menurunkan kualitas sumber daya manusia (KEMENTRIAN KESEHATAN, 2012).

Secara umum terdapat dua cara masuknya nematoda usus dalam menginfeksi tubuh manusia, yaitu melalui mulut dan kulit. Telur-telur dapat masuk ke dalam tubuh manusia, melalui konsumsi sayuran yang proses pencuciannya tidak bersih dan tidak dimasak atau secara langsung melalui tangan yang tercemar telur cacing yang infektif (Nugroho, 2010).

Sayuran merupakan makanan pendamping makanan pokok yang kaya gizi. Di dalam sayuran terkandung serat yang tinggi, protein, vitamin dan mineral yang penting bagi tubuh. Sayuran terutama yang biasa digunakan untuk lalapan yang dicuci bersih kemungkinan besar masih mengandung telur cacing. Penyebaran cacing usus pada makanan sayuran dapat terjadi antara lain karena kekurangan pengetahuan pengelolaan dan langkah-langkah pencegahannya dari petani sampai tingkat konsumen. (Nugroho, 2010)

Sayuran yang biasa dimakan mentah sebagai lalapan meliputi daun pohpohan, daun selada, daun kemangi, daun kenikir, mentimun, kacang panjang, tomat dan masih banyak lagi. Penjualan sayuran tersebut dapat ditemukan di pasar tradisional maupun di supermarket. Rata-rata para pedagang yang menjual sayuran lalapan di pasar tradisional tidak mementingkan tentang kualitas kebersihan sayuran yang diperjual-belikan untuk di konsumsi. Kebiasaan memakan lalapan mentah yang tidak dicuci dengan bersih menyebabkan kemungkinan lalapan sebagai sumber penularan nematoda usus.

Pasar embrio adalah salah satu pasar tradisional di Kecamatan Makasar Jakarta Timur yang menjual berbagai keperluan masyarakat, di antaranya adalah sayuran termasuk lalapan. Lalapan-lalapan yang 
dijual di pasar ini diletakan di kios-kios dengan meja penjualan seadanya di tempat terbuka dan sebagian stok sayuran yang akan dijual disimpan dan diletakan di lantai di bawah meja penjualan tanpa menggunakan alas. Selain itu di pasar ini mencampur penjualan berbagai bahan daging segar dicampur dengan sayuran dan bahan lainnya sehingga mengundang datangnya lalat. Kondisi ini dapat memungkinkan sayuran akan tercemar oleh telur nematoda usus dan kotoran-kotoran lain yang terbawa lalat atau udara. Sepanjang pengetahuan penulis, di lokasi ini belum pernah dilakukan penelitian tentang pencematan telur nemtoda usus pada lalapan. Penulis tertarik untuk melakukan penelitian di pasar ini untuk mengetahui seberapa tinggi angka pancemaran telur nematoda usus terhadap lalapan. Untuk membuktikan adanya pencemaran terhadap sayuran maka dilakukan penelitian terhadap lalapan daun pohpohan, daun kenikir, dan buah kacang panjang yang dijual di pasar tradisional di Jakarta Timur.

\section{METODE PENELITIAN}

Penelitian ini merupakan penelitian deskriptif. Desain penelitian ini adalah survei potong lintang (cross sectional). Penelitian dilaksanakan di Pasar Tradisional Embrio Kecamatan Makasar, Jakarta Timur. Penelitian dilaksanakan pada tanggal 10 Agustus sampai 24 Agustus 2019. Populasi penelitian ini adalah lalapan daun pohpohan, daun kenikir dan buah kacang panjang yang dijual di Pasar Tradisional Embrio Kecamatan Makasar Jakarta Timur. Unit sampel penelitian ini adalah lalapan pohpohan, kenikir dan kacang panjang yang dijual di 5 pedagang lalapan yang berada di Pasar Tradisional Embrio Kecamatan Makasar Jakarta Timur. Kriteria sampel yaitu:

1) Kriteria Inklusi

a. Jenis lalapan adalah daun pohpohan, atau daun kenikir, atau buah kacang panjang.

b. Lalapan dijual di Pasar Embrio Kecamatan Makasar, Jakarta Timur.

c. Lalapan yang dijual berasal dari hasil pertanian dari sekitar Jakarta.

d. Penjual bersedia diwawancarai.

2) Kriteria Eksklusi

a. Lalapan tidak segar (mengering atau sudah busuk).

b. Lalapan tercampur aduk dengan sayuran lain.

Sampel dipilih dengan "non probability sampling". Jumlah sampel dihitung dengan mempertimbangkan sebaran menurut: jumlah penjual, jumlah jenis lalapan, volume yang dijual, dan jumlah kali pengambilan sebagai berikut:

Jumlah sampel $=5$ penjual lalapan $\mathrm{x} 3$ jenis lalapan $\mathrm{x} 1$ ikat $\mathrm{x} 10$ kali pengambilan $=150$ Sampel .

Data yang diperoleh dalam penelitian ini dianalisis dengan dua cara sebagai berikut:

1. Analisis Univariat

Untuk menentukan besarnya angka pencemaran. Angka pencemaran tersebut dihitung dengan rumus berikut: 


$$
\text { Angka Pencemaran }=\frac{\text { Jumlah sampel positif }}{\text { Jumlah sampel seluruhnya }} \times 100 \%
$$

2. Analisis Bivariat

Untuk mengetahui hubungan tindakan pencucian dengan angka pencemaran telur nematoda usus pada lalapan, data dianalisis dengan menggunakan uji chi-square. Data diolah dengan menggunakan aplikasi SPSS 20.0. Batas penerimaan kesalahan adalah 0,05 $(\mathrm{P}=0,05)$. Bila $\mathrm{P}<0,05$ berarti ada hubungan yang bermakna/signifikan dan bila $\mathrm{P}>0,05$ berarti tidak ada hubungan/tidak signifikan.

\section{HASIL DAN PEMBAHASAN}

\section{Hasil Penelitian}

Pasar Embrio merupakan satu-satunya pasar tradisional yang terletak di Kecamatan Makasar Jakarta Timur. Di pasar ini sayur dijual sesuai dengan distribusi penjual atau tidak terfokus di satu tempat dan dicampur dengan bahan bahan penjualan lain. Selain menjual sayuran para pedagang di pasar ini menjual bahan bahan pokok lainnya. Kondisi kebersihan pasar ini masih kurang diperhatikan dan hal itu tergambar dari cara para penjual sayuran meletakan dan menyimpan dagangan sayurannya di lantai atau tanah tanpa alas. Suasana pasar tradisional Embrio dapat dilihat pada Gambar 4.1.

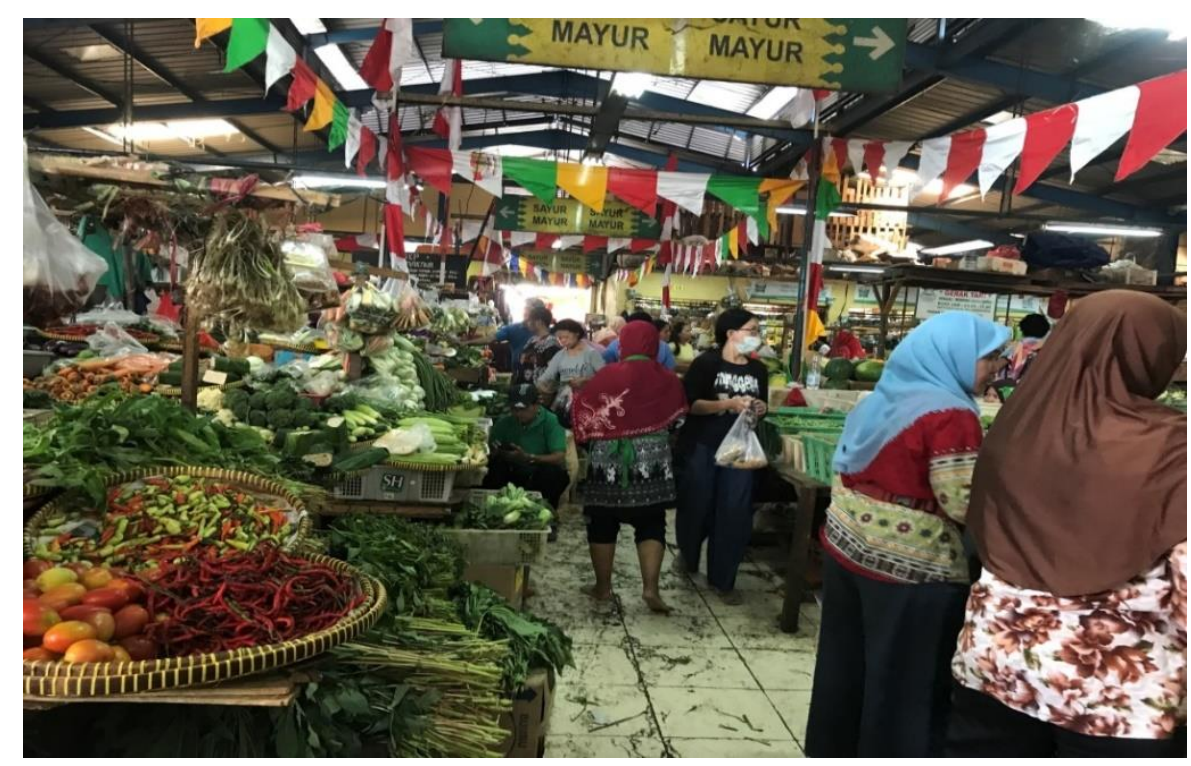

Gambar 4.1.

Suasana Lingkungan Di Pasar Tradisional Embrio

Kecamatan Makasar Jakarta Timur.

Diantara 150 sampel lalapan yang terdiri dari 50 sampel daun pohpohan, 50 sampel daun kenikir dan 50 sampel buah kacang panjang yang diperiksa, jumlah yang positif telur nematoda usus adalah 7 sampel (Positive Rate atau besarnya angka pencemaran $=4,7 \%$ ). Jumlah sampel positif menurut jenis lalapan 
adalah lalapan daun pohpohan sebanyak 4 sampel (8\%), daun kenikir sebanyak 2 sampel (4\%) dan buah kacang panjang sebanyak 1 sampel (2\%). Seperti tertera pada Tabel 4.1.

Tabel 4.1.

Distribusi Frekuensi Telur Nematoda Usus Menurut Jenis Lalapan Yang Diperiksa Pada Pasar Embrio Kecamatan Makasar Jakarta Timur, 2019.

\begin{tabular}{cccc}
\hline Jenis Lalapan & $\begin{array}{c}\text { Jumlah Yang } \\
\text { Diperiksa }\end{array}$ & $\begin{array}{c}\text { Jumlah Yang } \\
\text { Positif }\end{array}$ & $\begin{array}{c}\text { Persentase } \\
\text { Positif }\end{array}$ \\
\hline Daun Pohpohan & 50 & 4 & $4 / 50(8 \%)$ \\
\hline Daun Kenikir & 50 & 2 & $2 / 50(4 \%)$ \\
\hline $\begin{array}{c}\text { Buah Kacang } \\
\text { Panjang }\end{array}$ & 50 & 1 & $1 / 50(2 \%)$ \\
\hline Jumlah & 150 & 7 & $7 / 150(4,7 \%)$ \\
\hline
\end{tabular}

Spesies telur nematoda usus yang ditemukan pada lalapan daun pohpohan, daun kenikir dan buah kacang panjang di Pasar Tradisional Embrio Kecamatan Makasar Jakarta Timur dapat dilihat pada Tabel 4.2. Dari 7 sampel positif, spesies telur nematoda usus yang ditemukan adalah Ascaris lumbricoides 5 $(71,4 \%)$ dan Trichuris trichiura $2(28,6 \%)$ dengan pembagian menurut jenis sayuran yaitu, 4 sampel positif pada daun pohpohan terdapat 3 sampel (75\%) positif telur Ascaris lumbricoides dan 1 sampel (25\%) positif telur Trichuris trichiura. Diantara 2 sampel positif daun kenikir terdapat 1 sampel (50\%) positif Ascaris lumbricoides dan 1 sampel (50\%) positif telur Trichuris trichiura. Dari 1 sampel buah kacang panjang seluruhnya (100\%) hanya positif telur Ascaris lumbricoides. Gambar identifikasi jenis telur dapat dilihat pada Gambar 4.2. dan Gambar 4.3.

Tabel 4.2.

Jumlah Yang Positif Telur Nematoda Usus Menurut Jenis Lalapan Dan Spesies Telur Yang Ditemukan.

\begin{tabular}{cccc}
\hline \multirow{2}{*}{ Jenis Lalapan } & \multicolumn{2}{c}{ Jumlah Dalam Persen Menurut Spesies } & \\
\cline { 2 - 3 } & $\begin{array}{c}\text { Ascaris } \\
\text { lumbricoides }\end{array}$ & Trichuris trichiura & Jumlah \\
\hline $\begin{array}{c}\text { Daun } \\
\text { Pohpohan }\end{array}$ & $3 / 4(75 \%)$ & $1 / 4(25 \%)$ & 4 \\
\hline Daun Kenikir & $1 / 2(50 \%)$ & $1 / 2(50 \%)$ & 2 \\
\hline $\begin{array}{c}\text { Buah Kacang } \\
\text { Panjang }\end{array}$ & $1 / 1(100 \%)$ & $0 / 1(0 \%)$ & 1 \\
\hline Jumlah & $5 / 7(71,4 \%)$ & $2 / 7(28,6 \%)$ & 7 \\
\hline
\end{tabular}




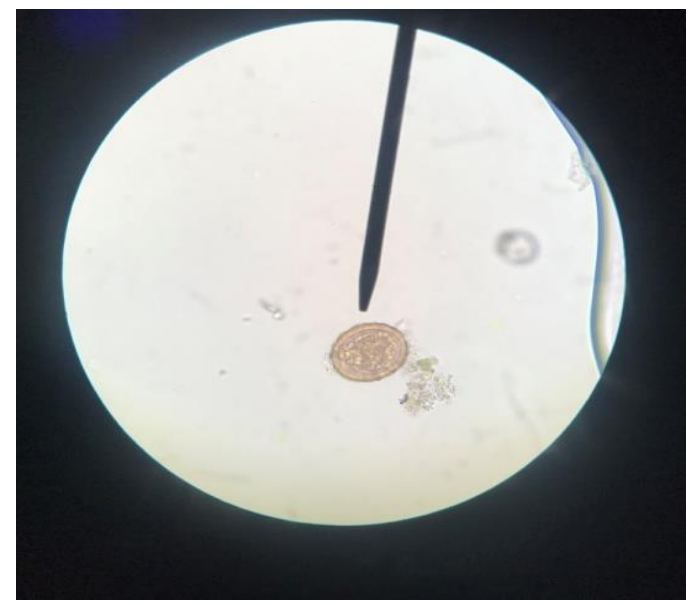

Gambar 4.2.

Telur Ascaris lumbricoides Dibuahi

Pada Pembesaran 10x40.

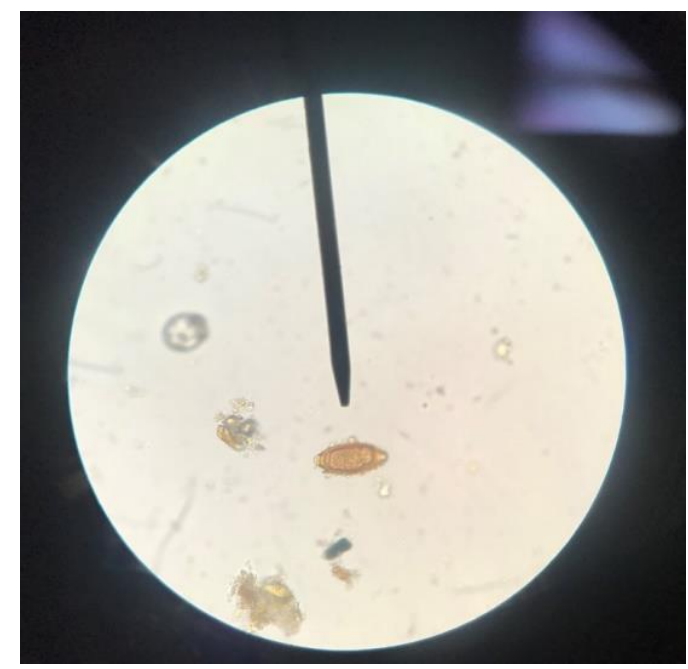

Gambar 4.3.

Telur Trichuris trichiura

Pada Pembesaran 10x40.

Pada Tabel 4.3. diperlihatkan jumlah lalapan yang positif oleh telur nematoda usus menurut proses pencucian lalapan. Berdasarkan hasil wawancara terhadap penjual yang menjual lalapan daun pohpohan, daun kenikir dan buah kacang panjang di Pasar Tradisional Embrio Kecamatan Makasar Jakarta Timur diperoleh informasi bahwa dari 150 sampel seluruhnya didapatkan dari distributor, dimana 54 sampel dicuci lebih dari 1 kali dan 96 sampel dicuci hanya 1 kali. Jumlah yang positif telur nematoda usus menurut proses pencucian pada frekuensi pencucian $>1$ kali adalah 3,7\% (2/54), sedangkan yang positif pada frekuensi pencucian hanya $1 \mathrm{kali}$ adalah 5,2\% (5/96). Dengan uji chi-square, persentase yang positif pada kedua kategori tersebut tidak berbeda bermakna $(P>0,05)$. Dengan perkataan lain, tidak 
ada hubungan antara frekuensi pencucian $>1$ kali dan hanya 1 kali dengan pencemaran telur nematoda usus.

Pada proses cara penggantian air pencuci diketahui 84 sampel dilakukan pencucian dengan menggunakan air mengalir dan 66 sampel dilakukan pencucian dengan menggunakan air tidak mengalir atau ditampung di ember, hanya direndam dan dikibas-kibas. Jumlah yang positif telur nematoda usus menurut proses pencucian pada penggantian air pencuci secara mengalir adalah 1,2\% (1/84), sedangkan yang positif pada cara penggantian air pencuci secara tidak mengalir adalah 9,1\% (6/66). Dengan uji chi-square, persentase yang positif tersebut pada kedua kategori berbeda bermakna $(\mathrm{P}<0,05)$. Dengan perkataan lain ada hubungan antara cara penggantian air pencuci secara air mengalir dan tidak mengalir dengan pencemaran telur nematoda usus.

Pada proses cara pencucian menurut pencampuran jenis lalapan diketahui 21 sampel dicuci dengan perlakuan lebih dari 1 jenis sayuran dan 129 sampel dicuci dengan perlakuan hanya 1 jenis sayuran. Jumlah yang positif telur nematoda usus menurut proses pencucian dengan pencampuran jenis lalapan dicampur $>1$ jenis sayuran adalah 23,8\% (5/21), sedangkan yang positif pada proses pencucian hanya 1 jenis sayuran adalah 1,6\% (2/129). Dengan uji chi-square, bahwa persentase yang positif pada kedua kategori tersebut berbeda bermakna $(\mathrm{P}<0,05)$. Dengan perkataan lain ada hubungan antara cara pencucian menurut pencampuran jenis lalapan $>1$ jenis lalapan dan hanya 1 jenis lalapan dengan pencemaran telur nematoda usus. Hasil-hasil semua perhitungan statistik chi-square dapat dilihat pada Lampiran 3.

\section{Tabel 4.3.}

Hubungan Antara Variabel Yang Diteliti Dengan Pencemaran Telur Nematoda Usus Pada Lalapan Yang Dijual Di Pasar Tradisional Embrio Kecamatan Makasar Jakarta Timur, 2019.

\begin{tabular}{|c|c|c|c|c|c|c|}
\hline \multirow{2}{*}{ No } & \multirow{2}{*}{ Variabel Yang Diteliti } & \multicolumn{3}{|c|}{ Hasil Pemeriksaan } & \multirow{2}{*}{ Nilai $P$} & \multirow[t]{2}{*}{ Kesimpulan } \\
\hline & & Positif & Negatif & Jumlah & & \\
\hline \multicolumn{7}{|c|}{1 Frekuensi Pencucian } \\
\hline & $\begin{array}{l}>1 \text { kali } \\
1 \text { kali }\end{array}$ & $\begin{array}{c}2 \\
(3,7 \%) \\
5 \\
(5,2 \%) \\
\end{array}$ & $\begin{array}{c}52 \\
(96,3 \%) \\
91 \\
(94,8 \%)\end{array}$ & $\begin{array}{c}54 \\
(100,0 \%) \\
96 \\
(100,0 \%)\end{array}$ & \multirow[t]{2}{*}{1,000} & \multirow[t]{2}{*}{$\begin{array}{l}\text { Tidak ada } \\
\text { hubungan }\end{array}$} \\
\hline & Total & $\begin{array}{r}7 \\
(4,7 \%) \\
\end{array}$ & $\begin{array}{c}143 \\
(95,3 \%) \\
\end{array}$ & $\begin{array}{c}150 \\
(100,0 \%) \\
\end{array}$ & & \\
\hline \multirow[t]{3}{*}{2} & Cara Penggantian Air Pencuci & & & & & \\
\hline & $\begin{array}{l}\text { Air mengalir } \\
\text { Air tidak mengalir }\end{array}$ & $\begin{array}{c}1 \\
(1,2 \%) \\
6 \\
(9,1 \%) \\
\end{array}$ & $\begin{array}{c}83 \\
(98,8 \%) \\
60 \\
(90,9 \%) \\
\end{array}$ & $\begin{array}{c}84 \\
(100,0 \%) \\
66 \\
(100,0 \%) \\
\end{array}$ & \multirow[t]{2}{*}{0,044} & \multirow[t]{2}{*}{$\begin{array}{c}\text { Ada } \\
\text { hubungan }\end{array}$} \\
\hline & Total & $\begin{array}{c}7 \\
(4,7 \%)\end{array}$ & $\begin{array}{c}143 \\
(95,3 \%)\end{array}$ & $\begin{array}{c}150 \\
(100,0 \%)\end{array}$ & & \\
\hline
\end{tabular}

Cara Pencucian menurut

3 Penvampuran Jenis Lalapan 


\begin{tabular}{|c|c|c|c|c|c|}
\hline Dicampur $>1$ jenis sayuran & $\begin{array}{c}5 \\
(23,8 \%)\end{array}$ & $\begin{array}{c}16 \\
(76,2 \%)\end{array}$ & $\begin{array}{c}21 \\
(100,0 \%)\end{array}$ & & \\
\hline Hanya 1 jenis sayuran & $\begin{array}{c}2 \\
(1,6 \%)\end{array}$ & $\begin{array}{c}127 \\
(98,4 \%)\end{array}$ & $\begin{array}{c}129 \\
(100,0 \%)\end{array}$ & 0,001 & $\begin{array}{c}\text { Ada } \\
\text { hubungan }\end{array}$ \\
\hline Total & $\begin{array}{c}7 \\
(4,7 \%)\end{array}$ & $\begin{array}{c}143 \\
(95,3 \%)\end{array}$ & $\begin{array}{c}150 \\
(100,0 \%)\end{array}$ & & \\
\hline
\end{tabular}

\section{Pembahasan}

Pada penelitian ini didapatkan hasil dari 150 sampel lalapan daun pohpohan, daun kenikir dan buah kacang panjang yang diperiksa dari Pasar Tradisional Embrio Kecamatan Makasar Jakarta Timur, angka pencemaran telur nematoda usus adalah 4,7\% (7/150).

Angka pencemaran pada hasil penelitian ini yang besarnya 4,7\% (7/150) jauh lebih rendah dibandingkan dengan beberapa hasil penelitian lain, antara lain oleh Lobo dkk tahun 2016 pada kemangi yang angka pencemarannya 39,7\% (Lobo dkk, 2016). Demikian juga dengan hasil penelitian Suryani tahun 2012 dimana angka pencemaran pada kubis adalah $23,1 \%$, hasil penelitian ini juga lebih rendah (Suryani, 2012). Dibandingkan dengan hasil penelitian Karthikraj tahun 2017, hasil penelitian ini juga lebih rendah. Perbedaan (lebih kecilnya) angka pencemaran tersebut dapat disebabkan oleh beberapa hal, antara lain perbedaan jumlah sampel, perbandingan komposisi jenis sayuran, sumber sayuran (berasal dari petani atau bukan) cara pencucian dan sumber air pencuci.

Angka pencemaran yang didapat pada lalapan tersebut dapat dipengaruhi oleh beberapa faktor salah satunya adalah dilihat dari bentuk daun pohpohan yang berbentuk lebar, memiliki lekukan pada permukaan daun yang dapat membuat telur nematoda usus yang berukuran mikroskopik mudah melekat ketika terbang bersama debu dan menempel pada permukaan daun, serta kurangnya kesadaran akan pencucian pada sayuran terutama sayuran yang dimakan mentah seperti pencucian yang tidak lebih dari 1 kali dan tidak menggunakan air mengalir atau hanya sekedar dikibas kibas saja didalam wadah berisi air yang diam.

Daun pohpohan merupakan jenis lalapan yang tertinggi angka pencemaran telur nematoda usus diantara ketiga jenis sayuran tersebut. Hal itu kemungkinan karena daun pohpohan memiliki bulu-bulu di permukaan daunnya sehingga memungkinkan telur nematoda usus melekat di antara bulu-bulu tersebut. Sebaliknya permukaan bulu kacang panjang relatif bersih tanpa bulu sehingga telur nematoda usus relatif lebih sedikit melekat.

Telur nematoda usus yang ditemukan mencemari lalapan tersebut hanya dua spesies (Ascaris lumbricoides dan Trichuris trichiura) dengan pesentase tertinggi telur Ascaris lumbricoides. Hal itu karena telur Ascaris lumbricoides memiliki persebaran terluas di dunia dan merupakan penyebab utama penyakit kecacingan pada manusia di negara tropis dan sub tropis. Karena sumber telur nematoda usus yang mencemari lalapan tersebut adalah feses manusia, maka prevalensi infeksi Ascaris lumbricoides yang paling tinggi menyebabkan pencemaran. Selain itu juga kemungkinan karena jumlah telur yang dihasilkan oleh Ascaris lumbricoides cukup banyak jika dibandingkan dengan spesies cacing parasit 
lainnya. Setiap cacing betina Ascaris lumbricoides dewasa mampu bertelur sampai 200.000 telur per hari, sedangkan cacing betina Trichuris trichiura bertelur 3000-20.000 telur per hari, dan cacing tambang betina dewasa bertelur 9000-10.000 telur per hari. Kontaminasi Ascaris lumbricoides biasanya diikuti pula dengan kontaminasi Trichuris trichiura. Hal ini disebabkan oleh penyebaran Ascaris lumbricoides dan Trichuris trichiura mempunyai pola yang hampir sama baik suhu optimum maupun waktu perkembangan di tanah.

Tidak ditemukannya telur cacing tambang pada penelitian ini dapat disebabkan karena beberapa faktor diantaranya yaitu jumlah telur yang dihasilkan oleh cacing tambang yaitu sekitar 9000-10.000 telur per hari, jumlah ini merupakan jumlah yang paling sedikit jika dibandingkan dengan telur yang dihasilkan oleh Ascaris lumbricoides dan Trichuris trichiura, serta dimungkinkan sudah menetasnya telur cacing tambang sehingga sudah tidak ditemukan pada saat pemeriksaan. Faktor lainnya yaitu jenis tanah, telur cacing tambang dapat tumbuh optimum pada lingkungan yang mengandung pasir karena pasir memiliki berat jenis yang lebih besar dari pada air. Suhu juga merupakan faktor yang mempengaruhi pertumbuhan telur cacing tambang (Suryani, 2012).

Menurut Hadidjadja (2011), sayuran lalapan yang baik seharusnya dicuci dengan air mengalir selama 30 detik, akan tetapi masih banyak yang mencuci lalapan dengan menggunakan air di dalam ember dan tidak dilakukan penggantian air setiap pencucian sehingga akan menempel kembali telur ke lalapan.

Mencuci lalapan dengan menggunakan air tidak mengalir dapat berpeluang besar apabila terdapat telur cacing maka masih dapat tetap menempel atau kotoran yang tadinya terlepas dapat menempel kembali di lalapan. Cara pencucian dengan menggunakan air mengalir akan membuat lalapan menjadi bersih, karena air yang datang ke lalapan dalam kondisi masih bersih dan akan membawa kotoran, debu, kuman, parasit, dan lain sebagainya ke air buangan yang telah terlepas dan terbawa air sehingga tidak akan bisa mencemari lalapan.

Perlakuan dalam cara pencucian dengan hanya satu jenis lalapan akan membuat lalapan tidak terkontaminasi dengan lalapan yang mengandung telur cacing dibandingkan dengan mencuci lalapan yang mencampur lebih dari 1 jenis lalapan yang dapat menyebabkan terkontaminasi dari jenis lalapan yang berbeda.

Sayuran yang ditata di tempat yang terbuka dan tidak bersih dapat tercemar oleh telur cacing. Telur cacing yang ada di tanah atau debu akan terbawa oleh angin dan sampai pada makanan. Selain itu transmisi telur cacing juga dapat melalui lalat yang sebelumnya hinggap di tanah atau kotoran, sehingga kaki-kakinya membawa telur cacing dan mencemari makanan-makanan yang tidak tertutup (Verdira, 2014).

Pencemaran telur nematoda usus pada lalapan daun pohpohan, daun kenikir dan buah kacang panjang yang berhubungan dengan proses pencucian yaitu pada cara penggantian air pencuci dan cara pencucian menurut pencampuran jenis lalapan. 
Dari hasil dalam penelitian ini, konsumen harus tetap waspada terhadap sayuran yang akan dimakan dengan cara selalu menjaga kebersihan, karena sayuran dapat menjadi salah satu sumber infeksi kecacingan terutama pada masyarakat yang gemar memakan sayuran mentah atau yang sering disebut sebagai lalapan. Sebaiknya sayuran tersebut harus diolah dengan baik sehingga memenuhi syarat-syarat keamanan pangan, karena jika tidak dicuci dengan bersih atau diolah dengan baik maka telur cacing akan masuk ke dalam tubuh dan berkembang biak di dalam tubuh.

Angka pencemaran telur nematoda usus pada lalapan daun pohpohan, daun kenikir dan buah kacang panjang yang dijual di Pasar Tradisional Embrio Kecamatan Makasar Jakarta Timur perlu diwaspadai karena angka tersebut dapat menginfeksi manusia melalui menelan telur nematoda usus yang terdapat pada lalapan tersebut.

\section{SIMPULAN}

Dari hasil penelitian ini dapat diambil kesimpulan sebagai berikut: Besarnya angka pencemaran telur nematoda usus pada lalapan daun pohpohan, daun kenikir dan buah kacang panjang yang dijual di Pasar Tradisional Embrio Kecamatan Makasar Jakarta Timur adalah 4,7\% (7/150). Jenis telur nematoda usus yang mencemari lalapan daun pohpohan, daun kenikir dan buah kacang panjang ada 2 jenis yaitu Ascaris lumbricoides dan Trichuris trichiura. Tidak ada hubungan antara frekuensi pencucian dengan pencemaran telur nematoda usus pada lalapan daun pohpohan, daun kenikir dan buah kacang panjang yang dijual di Pasar Tradisional Embrio Kecamatan Makasar Jakarta Timur. Ada hubungan antara cara penggantian air pencuci dengan pencemaran telur nematoda usus pada lalapan daun pohpohan, daun kenikir dan buah kacang panjang yang dijual di Pasar

Tradisional Embrio Kecamatan Makasar Jakarta Timur. Ada hubungan antara cara pencucian menurut pencampuran jenis lalapan dengan pencemaran telur nematoda usus pada lalapan daun pohpohan, daun kenikir dan buah kacang panjang yang dijual di Pasar Tradisional Embrio Kecamatan Makasar Jakarta Timur.

\section{UCAPAN TERIMA KASIH}

Penulis mengucapkan terima kasih kepada Kepala Laboratorium Biologi Universitas MH Thamrin dan Prodi D III Analis Kesehatan Universitas MH Thamrin berperan serta dalam penelitian ini.

\section{DAFTAR PUSTAKA}

1. Hadidjaja, P., dan Margono, S.S. 2011. Dasar Patologi Klinik, FKUI, Jakarta.

2. Handayani. D. 2007. Identifikasi Karakter Hortikultura Beberapa Sayuran Indigenous, Skripsi Sarjana, IPB, Bogor.

3. http://www.indonewz.com/2018/03/tak-disangka-ternyata-daun-pohpohan.html// (diakses tanggal 19 April 2019). 
4. https://hellosehat.com/hidup-sehat/fakta-unik/manfaat-daun-kenikir-untuk-kesehatan/ (diakses tanggal 19 April 2019).

5. https://sentrabudidaya.com/cara-menanam-kacang-panjang/ (diakses tanggal 19 April 2019).

6. Ideham, B. 2007. Helmintolohgi Kedokteran, Cetakan Pertama. Airlangga University Press. Surabaya.

7. Irianto, K. 2009. Panduan Praktikum Parasitologi Dasar Untuk Paramedis dan Nonmedis, Yrama Widya. Bandung.

8. Kementrian Kesehatan RI Direktorat Jendral PP dan PL. 2012. Pedoman Pengendalian Kecacingan. Jakarta.

9. Karthikraj K. 2017. Pencemaran Soil Transmitted Helminth Pada Sayuran Lalapan Di LadangLadang Sayur Di Kelurahan Merdeka, Kecamatan Merdeka, Kabupaten Karo, Skripsi Sarjana Universitas Sumatera Utara, Sumatera Utara.

10. Lobo. L, Widhadha. J, Octaviani Dkk. 2016. Kontaminasi Telur Soil Transmitted Helminth (STH) Pada Sayuran Kemangi Pedagang Ikan Bakar Di Kota Palu Sulawesi Tengah. Media Litbangkes, Vol. 26 No. 2, Sulawesi Tengah.

11. Margono, S.S,. dan Abidin, S.A.N,. 2006. Nematoda Usus dalam Parasitologi Kedokteran, Gandahusada, S. dkk (Eds), Edisi 3, FKUI, Jakarta.

12. Munthe, D.S., 2004. Analisa Telur dan Larva Cacing Pada Selada yang Terdapat Pada Makanan Burger Yang di Jajakan Sekitar Kampus USU Medan, Skripsi Sarjana, USU, Medan.

13. Nugroho, Haryanto, S,. 2005. Sehat dan Bugar Secara Alami, Penebar Plus, Depok.

14. Nugroho, Cahyo., dkk. 2010. Identifikasi Kontamnasi Telur Nematoda Usus pada Sayuran Kubis (Brassica oleracea) Warung Makan Lesehan Wonosari Gunung Kidul Yogyakarta Tahun 2010. Jurnal kesmas Uad V: 4. Yogyakarta.

15. Safar, R., 2009. Parasitologi Kedokteran: Protozologi, Entomologi, dan Helmintologi. Cv. Yrama Widya, Jakarta.

16. Sandjaja, R,. 2007. Parasitologi Kedokteran : Helmintologi Kedokteran, Prestasi Pustaka, Jakarta.

17. Sasongko, A., 2010. Bahaya Cacingan Untuk Anak dan Dewasa, Direktur Pelayanan Kesehatan di Yayasan Kusuma Buana.

18. Siahaan, R.O.I., 2010. Isolasi Salmonella sp. Pada Sayuran di Wilayah Bogor dan Evaluasi Pengaruh Perilaku Pencucian Ddengan Sanitasi Komersial, Skripsi, Institut Pertanian Bogor, Bogor.

19. Soedarto, DTMH., PhD. 2011. Buku Ajar Parasitologi Kedokteran, CV Sagung Seto, Jakarta.

20. Sulistyaningsih, 2019. Penyakit Infeksi Parasit Di Indonesia, Cetakan Pertama, Penerbit Trans Info Media, Jakarta.

21. Supali, T., S.S Margono, S. Alisah, N. Abidin. 2008. Parasitologi kedokteran edisi kedua. Sagung Seto. Surabaya. 
22. Suryani. D. 2012. Hubungan Perilaku Mencuci Dengan Kontaminasi Telur Nematoda Usus Pada Sayuran Kubis Pedagang Pecel Lele Di Kelurahan Warungboto Kota Yogyakarta, Yogyakarta. Jurnal Kesmas UAD. Yogyakarta.

23. Sutanto, I,. dkk, 2008. Buku Ajar Parasitologi Kedokteran, Edisi Keempat, Balai Penerbit FKUI, Jakarta.

24. Verdira. 2014. Distribusi Frekuensi Soil Transmitted Helminth Pada Sayuran Selada (Lactuca sativa) yang Dijual Di Pasar Tradisional dan Pasar Modern Di Kota Padang. Jurnal FK UNAND. Padang.

25. $\quad$ www.dpd.cdc.gov (diakses tanggal 17 April 2019). 